$652.075 \cdot 3: 612 \cdot 46 \cdot 461$

\title{
尿中「ヒドロキノン」及ヒ「ブレンッカテキン」ノ 定量法媇二家鬼尿中含且二就テ
}

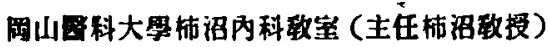 \\ 市 村 开 雄 \\ [昭和 10 年 6 月 20 日受棉] \\ Aus der Medizinischen K'linik der Okayama Med. Fakultät \\ (Vorstand: Prof. Dr. K. Kakinuma). \\ Über die Bestimnungsmethode des Hydrochinons und \\ Brenzkatechins in Harn und deren Gehalt \\ in Kaninchenharn. \\ Von \\ Ushio Ichimura. \\ Eingegangen am 20. Juni 1935.
}

Verfasser beschreibt in dieser Mitteilung seine Bestimmungsmethode von Brenzkatechiu uud Hydrochinon, die hauptsächlich nach dem Prinzip von
Er. Böck und G. Lock ausgeführt wurde. Zugleich wurden auch einige Bestimmungen ihres Gehaltes im Kaninchenharns beigefügt. (Autoreferat.)

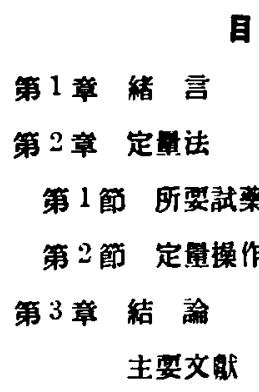

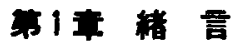

余八或生物學的研究二當りテ，尿中二於，

ル「ヒドロキノン」涉ニ「ブレンツカテキン」

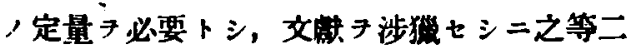
洒ノフェノール」純粹溶液中ョリノ定量法 二關三テハ從本数原試にラレタルチ知りタル モ，雜多ナ成分ョリ成ル展中ヨリ，定量法八 
之キ胃ザリキ．仍テ余ハ康中ョリ，定量二就 キ刵カ嘪驗フ試えタル處フリ，而シテ比較的

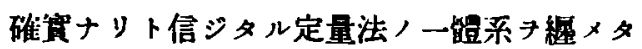
ルキ以テ，良二之キ記載シテ大方ノ批制卜叱 正ヨとハントス.

「ヒドロキノン」ト「ブレンシカテキン」トヨ其,

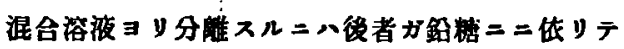

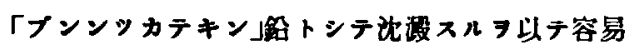

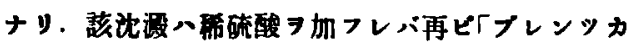
テキン」テ遊濩ス. 從來 Casolari(1909), Wieland (1910), Gardner u. Hodgson(1910), Pence(1913) 等ニ依りテ jodometrisch = 一部定量ガ行ハレタ 几モ，各く多少人缺點 キノン」そ「プレンッカテキン」モ,

OH

ノ如ク，酸化二体りテ「キンヒドロン」ヨ經テ夫ぬ

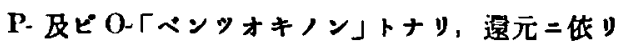
テ之等ノ「キノン」ハ復元二蹛ル. Fr. Böck u.

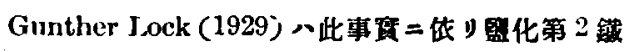
ヨ以テ各酸化シテ「キノン」トシテ、「キノン」ノ定 尹量行ーリ.「キノン」ノ定量八古クValeur(1899) Willstätter u. Majima (1909-1910)等 $=$ 依 ハレタルモ, Fr. Böck 等ハ「キ/ン」泬媒 $=「 ク$ ロロホルム」或ハ「ペンォール」习使用セり.

尿中二存在スル「rドロキノン」、 Atherschwefelsäure トシテ Phenol, Benzol キ服 用七ル時二多ク觀ラレ，馬尿二八正常二其， 痕跡キ證明サレ，及「レブレンッカテキン」ハ Brenzkatechinschwefelsäure $ト シ テ$ 存在シ， 植物二多ク含有サレル Protokatechusäure, Phenol 等ヨリ由來スルトサレ, 草食動物,
尿中二多ク，馬尿二八多量二證明サル，们 モ新䍀代謝，終末高物ナリ。

\section{第2辛 定量法}

第 1 篩 所要試絸

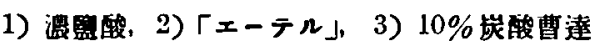

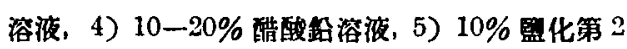

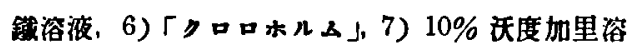
液，8）稀硫酸（約10\%），9） N/10 次亞曹達溶液、 10) $2 \%$ 搌枌溶液.

\section{第 2 節 定量操作}

\section{1. 尿, 處理}

尿《家鬼 $\ni$ 選ミ「クローバ一䈎

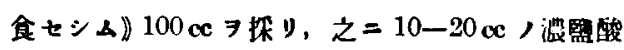

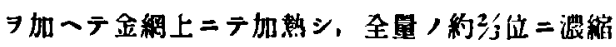
スレパ,「アムモ二十」, 揮破性脂肪䣬, 或ハ文「フ エノール」、「ハラクレゾール」等, 硫酸監モ分解 セラレテ大部分水蒸気卜共二揮散ス、命却媵同星 ハェーテル」ヨ加一，分液漏斗中=テ10-15分間

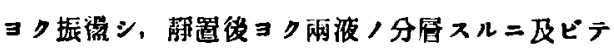

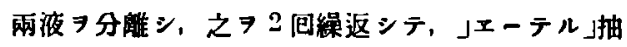

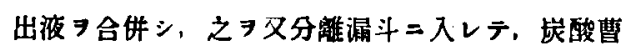

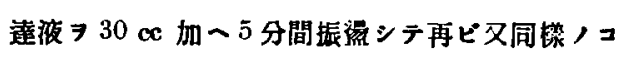

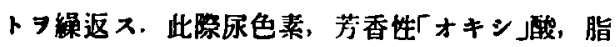
肪酸、鼠酸等八曹達花へ栘行ス，而シテ「ェーテ 儿」抽出液中二八䏚クトモ「ヒドロキノン」ト「ブレ ンッカテキン」トヨ把握溶解セリト解セラル. 此

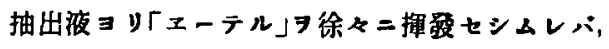
殘渣中=雨物貿，貽存. . 之二水 $750-100 \propto$ 加 ーテ溶解セシメ，之二最早沈搌ノ生ゼザル二至ル 迄鉛鈢水 離スル時八, 满液へ「ヒドキノン」ガ移行シ, 沈

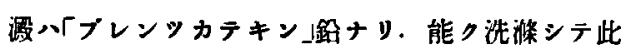

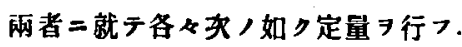


2.「ヒドキノン」定量

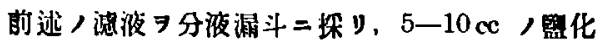

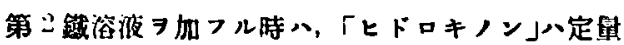
的二酸化サレテ「キノン」トナル. 次 $=50 \mathrm{cc}$ 位， 「クロロホルム」ヨ加へテ振篮シ「キノン」习抽出 ス，乙ヨ數他緝返シテ㣙出 $\exists$ 充分ナラシメ、「ク口 ロホルム」抽出渡 7 合阱シテ，之二沃度加里量溶

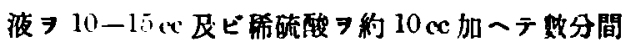

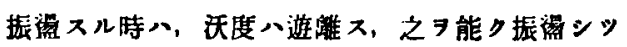
次亞硫酸䡒達溶液 着色ガ脫スルマデ滴定シ，最後二殷妢溶派 7 加一 テ滴定 7 完繥ス。此際「キノン」八透元セラレテ 「ヒドロキノン」トナリ，水㖊中一浴解サルル二至 几. 此方法二依儿時八假令他ノ「フェノール」類ガ 共存スル埸合二於テモ全然顀虑スル，要ナシ，師 チ一㵋ノ「フェノール」八過監化鐵卜八酸化物 7 作 ラザルモ「クロロホルム」中人溶解ス，然レドモ之 八酸性反㮩二於テ沃度 7 結合セザル故定星二八妨 ゲナシ. 欢レグルチン」「オルチン」「フロログ ルチン」等八過監化鐵ト作用スレドモ，其ノ䃏物 ハ「クロロホルム」中へ移行シ得ズ.「ピロガロー ル」「オキシヒドロキノン」八過監化鐵卜作用シ テ「クロロホルム可签性ノ「キノン」作ラザルモ 沈澱物 於テ筷化肰

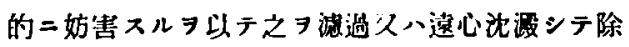
去シテ行フ時八正確度
3. 「フレレンツカテキン」定最法

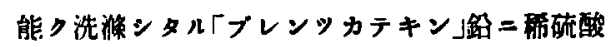

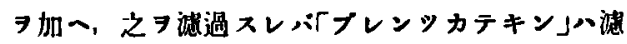
液二移行ス. 之二過監化鐵 $习$ 加一，「の口ロホル ム」ヨ以テ抽出スレパ，0-「ベンッォキノン」ハ「 口水儿内」一移行シテ緣色 7 呈ス. 之前卜同 樣ニシテ定量スレパ可ナリ.

4. 計算

斯ノ如クニシテ得タル所要次亞硫酸晢達漁液 acr トスレハ, $2 \mathrm{~T} カ 51$ 分子, $\mathrm{C}_{6} \mathrm{H}_{6} \mathrm{O}_{2}=$ 相當ス ルほ以、求ムル「ヒドロキ,ン」, 或ハ「ブレン シカテキン」/值 $\mathrm{x}$ 八狄ノ如クナル，即チ

$2 \times(126.92): 110.048=(0.012692) \times \mathrm{a}: \mathrm{x}$ $\therefore \mathrm{x}=0.0055024 \mathrm{a}$

5. 家鬼尿中 $ョ$ リ/定量成緽

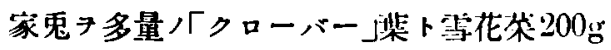
トア以テ们育三，其ノ尿二就前記，方法二 依ッテ测定七ル結果心「ヒドロキノン」八 $0.000605-0.002306 \mathrm{~g}, \Gamma$ 「レンッカテキン」ハ $0.000825-0.006878 \mathrm{~g}$ ナル數字キ得タリ.

次二尿 $300 \mathrm{cc}$ 集メ，之 3 分シテ其， 2 ツ人各々「ヒドルキノン」及ビ「プレンッカテ キン」キ $0.05 \mathrm{~g}$ 宛投入シ，今 1 ッ何物タモ

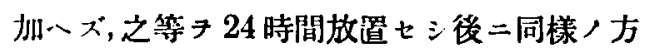

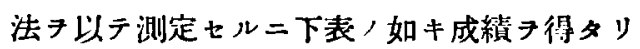

\begin{tabular}{|c|c|c|c|}
\hline 定昌項目 & 问物 $7 モ$ 加へザ几㽷 $100 \mathrm{cc}$ & $\begin{array}{l}\Gamma ヒ ト ゙ ロ キ ノ ン 」 0.05 \mathrm{~g} \\
\text { 尹加ータル尿 } 100 \mathrm{cc}\end{array}$ & $\begin{array}{l}\text { ブレンッカテキン」0.05 g } \\
\Rightarrow \text { 加一タル尿 } 100 \mathrm{ce}\end{array}$ \\
\hline 「ヒドロキノン」 & 0.00990332 & 0.00165072 & 0.001155504 \\
\hline 「ブレンッカテキン」 & 0.000440192 & 0.000385168 & 0.0018157 .92 \\
\hline
\end{tabular}


郎チ换メ加へタリシ「ヒドロキノン」及ビ「ブ レンッカテキン」八其, $1 / 10 モ$ 再憸出シ得ザ 得ルモノナリト信ズ。

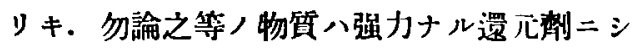

テ,之テ㲾中ニ加フレバ直二作用シ，自體八 其ノママニ存セザル八鲎然ナルベケレドモ,

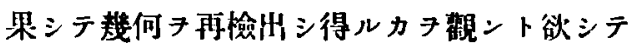
行ヒタルモノナリ。

\section{第3章 結 論}

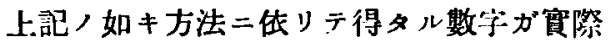
尿中二存在スル「ヒドロキノン」及ビ「ブレン ッカテキン」，量卜如何ナル锫係ニフルヒ， ナルヤ八，尿其ノモノガ極メテ複㒕ナル溶液 ニシテ之キ究明スルニ目下由ナク，璡テ全然 不明ニシテ今後，研究二カカル問題ナルモ， 現今之等物質，尿中カラ/定量方法二何等櫂 リタル確賽ナルナ法無キタ以テ，之ガ發見， 第一步トシテ，余，賽驗タ記載セルぞノナリ。 上述＼cjkstart操作、勿論猶ホ未ダ不完全ナルモノ= シテ改良サルベキナルハ物論ナルモ，尿ヨリ ノ抽出方法二何等力八改良 7 加几得レハ， Bock u. Lock 等力結品, 水溶液ヨり得タル 卜同樣，正碓度キテ，尿中實在量二對シテ或 ル一定，比率キ常二保持スル量丹數字的二示 シ得ルニ至り，隨テ其，消長ヨリ之等物質，

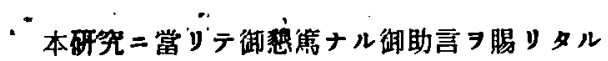

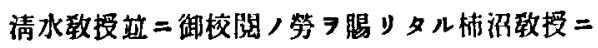
媌ンデ滿腃ノ謝意ヨ表ス。

\section{$\therefore$ 主要文战}

1) Bellsteins, Handl. d. orw. Chem. 2) Becher, Zentrall,l. f. inn. Med., Nr. 18, 1932. 3) Hans Meyer, Analyse n. Konstitntionsermittelung d. organ. Verheindung, 5 Auflage. 4）松井, 分析化舉. 5) Neutianer u. Irufpert, Analyse des Harns. 6) 清水歌授述，生化學

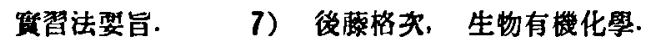
8）小竹無二婎，有機化煘，9）田中宗愛，

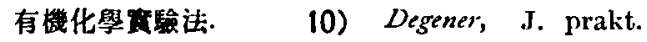
Chem., (2), $20 . \quad$ 11) Casolari, Gazz. chim. 'Ttaliana, 39, (1): Chem. centr., s. 365, 1909. 12) Wieland, Berichite D. cl. (i., 43, 1910. 13) Gardner u. Hodgson, J. chem. Soc. J.ondon, 9.; ; Chem. centr., T.S. 1910, 1909. 14) Pence, Med. Eng. chem. 5; ('he'm. centr., 1, s. 1727, 1913. 15) Ialen;, Compt. rend. 129 ; Chem. centr., 2, S. 906, 1899. 16) Willstitter 11. MIijima, Ber. D. chem. G., 43, S. 1171, 1910 ; 42, S. 2165, 1909. 17) Fr. Böck u. G. Lock, Monath. f. chem., 53-54, 1929. 